\title{
Carbon Stocks in Aboveground and Belowground Biomass of Sub-Humid Tropical Forest in Southwestern Nigeria
}

\section{Habeeb Ajibola Yusuf*, Jesumbo Joseph Oludipe, Oluwatoyin Olajumoke Adeoye, Idowu Ezekiel Olorunfemi}

Department of Agricultural and Environmental Engineering, School of Engineering and Engineering Technology,

Federal University of Technology, Akure, Nigeria

Email: *hayusuf@futa.edu.ng

How to cite this paper: Yusuf, H.A., Oludipe, J.J., Adeoye, O.O. and Olorunfemi, I.E. (2019) Carbon Stocks in Aboveground and Belowground Biomass of Sub-Humid Tropical Forest in Southwestern Nigeria. Open Access Library Journal, 6: e5588. https://doi.org/10.4236/oalib.1105588

Received: July 9, 2019

Accepted: July 30, 2019

Published: August 2, 2019

Copyright $\odot 2019$ by author(s) and Open Access Library Inc.

This work is licensed under the Creative Commons Attribution International License (CC BY 4.0).

http://creativecommons.org/licenses/by/4.0/

\begin{abstract}
This study aimed at estimation of carbon stocks in aboveground and belowground biomass of sub-humid young forest land in south-western Nigeria. Different species of trees were analysed. Results gathered indicated that the forest studied had an average aboveground carbon stock of live trees as $0.00407 \mathrm{t}$. Terminalia superba $(0.00698 \mathrm{t} \mathrm{C})$ has the highest carbon stocks and diameter at breast height $(\mathrm{Dbh})$ of $5.80 \mathrm{~cm}$ while Triplochiton scleroxylon contained the least stock of carbon $(0.00212 \mathrm{t} \mathrm{C})$ and Dbh of $3.55 \mathrm{~cm}$. From the analysis, it was observed that total belowground biomass (BGB) was $32 \%$ of AGB. Positive linear relationship was observed between $\mathrm{Dbh}$ and the amount of carbon in the study area. It was also observed that a negative linear relationship exists between the aboveground biomass carbon (AGBC) and wood densities. This study indicates that the species of trees in the forest studied are effective carbon sink and can inhibit the effect of $\mathrm{CO}_{2}$ in the atmosphere. Three new models were developed using different input parameters and they all showed proximity to the 2005 allometric equation by Chave and his team.
\end{abstract}

\section{Subject Areas \\ Environmental Sciences}

\section{Keywords}

Carbon Stock, Secondary Forest, Aboveground Biomass, Belowground Biomass

\section{Introduction}

Forestry and forest management has been recognized as one of the most efficient 
and cost effective means of addressing the challenges of increasing atmospheric carbon dioxide. Forests act as both sources and sinks of carbon. They are sources when they release carbon stored in their biomass to the atmosphere through deforestation and degradation, and they sink carbon from the atmosphere through photosynthesis and store it as biomass as they grow [1]. Forest can act as sink through the process of tree growth and resultant biological carbon sequestration. Carbon sequestration describes long term storage of carbon dioxide or other forms of carbon to reduce global warming and avoid various climate change effects. Forests sequester and store more carbon than any other terrestrial ecosystem and they are an important natural brake on climate change. In past decades, enormous research efforts have been made with the aim of finding ways of slowing down the climate change rate and subsequently mitigating its impacts [2] [3] [4] [5]. Forestry can make significance to a low cost global mitigation portfolio that provides synergies with adaptation and sustainable development [6]. The use of forest to sequester carbon dioxide is also another possible strategy to reduce greenhouse gases with great potential [7]. The forest ecosystem can capture and retain a large volume of carbon over long periods because trees are long-lived plants that develop a large biomass, thereby capturing a large amount of carbon over a growth cycle of many decades [8]. There are several methods of estimating aboveground carbon stocks in live trees. Organizations such as the California Climate Action Registry (CCAR) have suggested the use of generalized biomass Equations to quantify forest carbon stocks. The estimation of carbon stock in forest plantations is generally based on allometric Equations relating either carbon or biomass of diameter at breast height (Dbh) [9]. The allometric method directly calculates aboveground tree biomass by using Equations that express aboveground tree biomass as a function of diameter at breast height (Dbh) and/or tree height [10]. Destructive method is the most accurate means of biomass estimation but it is not cost effective. This research work was based on both destructive and non-destructive methods using volume Equations and wood density method for estimation of carbon stocks in stem of live trees of young forest and biomass expansion factors for the crown (including branches and leaves) carbon stock estimation. The aim of this research work was to estimate the carbon stocks in aboveground and belowground biomass of sub humid tropical forest in South-Western Nigeria. The specific objectives were to determine the contribution of the aboveground and belowground biomass to carbon stocks of tropical rainforests and determination of the aboveground/ belowground biomass ratio of trees in young tropical rainforests of South-western Nigeria.

\section{Material and Methods}

\subsection{Study Area}

The study area lies between Latitude $7.30^{\circ} \mathrm{N}$ and Longitude $5.13^{\circ} \mathrm{E}$ (Federal University of Technology, Akure, Ondo State) within the humid and tropical 
rainforest region of Nigeria [11]. It is $351 \mathrm{~m}$ above sea level and has a land area of about $2303 \mathrm{sq} \mathrm{km} \mathrm{[11].} \mathrm{Figure} 1$ shows the climograph of the main meteorological station around the study area. According to the Köppen-Geiger classification, the climate of the study area can be classified into Af (tropical rainforest) climate with significant rainfall for a larger part of the year and a short dry season. The average annual temperature is $26.7^{\circ} \mathrm{C}$, and the average annual rainfall is $1524 \mathrm{~mm}$. The driest month is December, with $19 \mathrm{~mm}$ of rainfall. In September, the precipitation reaches its peak, with an average of $405 \mathrm{~mm}$. The warmest month of the year is March, with an average temperature of $28.1^{\circ} \mathrm{C}$. At $25.2^{\circ} \mathrm{C}$ on average, July is the coldest month of the year. The relative humidity ranges between $80 \%$ and $100 \%$ during the rainy season and less than $60 \%$ during the dry season period [12].

\subsection{Data Collection}

Above ground biomass and carbon stocks of trees were estimated using allometric equation from [13], which are suitable for measurements of trees. Estimation of tree biomass was based on the equation that relates biomass to diameter at breast height (Dbh) and wood density (WD). During the measurements in this study, the height of the chest was $1.30 \mathrm{~m}$ above the ground for each tree as used by [14]. In the sample plot, trees with minimum Dbh of $3 \mathrm{~cm}$ were identified, numbered and measured. Measurements taken include wood density $(\rho)$ and diameter at breast height (Dbh) using the girth diameter tape. Random sampling method was adopted in establishing twenty sample trees consisting of five (5) species: Terminalia superba, Triplochiton scleroxylon, Clestopholis patens, Treculia rhinopetala and Antiaris africana on an acre of land. All the trees taken into consideration were $\geq 3 \mathrm{~cm}$ in trunk diameter. The goal of the sampling is to properly capture the variation in vegetation so that an unbiased estimate of carbon in the forest can be generated. Three soil samples were taken per tree sample; the following soil analyses were recorded: soil $\mathrm{pH}$, soil organic carbon composition and the soil textural classification. Carbon stocks were determined using both the destructive and non-destructive methods of estimating the aboveground biomass and belowground biomass of forests landscapes.

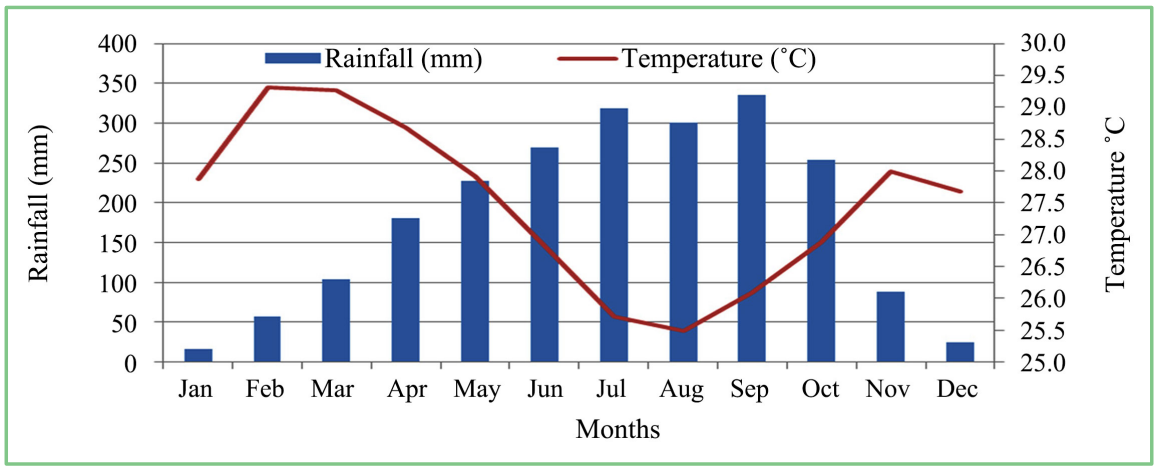

Figure 1. Climograph of the main meteorological station around the study area. 


\subsection{Data Processing and Analysis}

In order to parameterize local allometric models, a total of twenty trees comprising of five species were sampled destructively. These trees were sampled within 1 acre of the study area. Sample trees were selected in such a way that their size range (height and $\mathrm{Dbh}$ ) were as much as possible representative of the trees measured in the study area. After felling, diameter (Dbh) and height $(\mathrm{H})$ (equal to the length of the stem) of each individual sample tree were measured. Fresh weight of stems, branches and leaves were determined using a weighing balance with an accuracy of $\pm 0.1 \mathrm{~kg}$. All the leaves of each sample tree were collected manually and the fresh weight was recorded. Fresh leaves samples were taken to the laboratory for determination of dry-weight/fresh-weight ratio $(D w / F w)$. The leaf samples were dried at $70^{\circ} \mathrm{C} \pm 2{ }^{\circ} \mathrm{C}$ until a constant weight was achieved. Dry mass of the trees and leaves were determined based on the dry weight to fresh weight ratio as shown in Equation (1). Each wood sample was stored in a plastic bag to avoid water loss. Oven drying of wood samples for determination of fresh mass was done at $105^{\circ} \mathrm{C}$ to constant weight. The biomass ratio of each wood sample was calculated by the relation between dry-weight $(D w)$ and fresh-weight $\left(F_{W}\right)$ :

$$
B r=\frac{D w}{F w}
$$

Root to shoot ratio $(R: S)$ for each tree sample was determined by the relation between dry-weight $(D W)$ of stem and root:

$$
R: S=\frac{D w \text { of Root }}{D w \text { of Stem }}
$$

The belowground root biomass was estimated using trenches digging. Roots remaining in the soil were dug out as best as possible. Roots were divided into smaller parts by a saw and the soil was carefully removed by brushing. The fresh weight of the root system of each individual tree was determined and a sample was taken and oven-dried in the laboratory at $105^{\circ} \mathrm{C}$ to constant weight. Woody biomass of standing trees was determined based on diameter at breast height and basic wood density [15] [16]. Allometric model from [13] was used to measure the carbon stocks of aboveground biomass in the young forest plot. This equation is suitable for estimation of carbon stock of above ground-biomass in tropical region. Allometric equation from [17] is a mathematical equation used to estimate the carbon stock of below-ground biomass. To calculate the carbon stock using allometric equation from [13], two parameters were used; the wood density $(\rho)$ and diameter at breast height (Dbh). The total above ground biomass of each tree was estimated using allometric model from [13] as stated in Equation (3);

$$
\begin{aligned}
& \operatorname{AGB}(\mathrm{kg})=\rho * \exp \left(-1.239+1.980 \ln (\mathrm{D})+0.207(\ln (\mathrm{D}))^{2}-0.0281(\ln (\mathrm{D}))^{3}\right) \\
& \mathrm{AGB}=\text { Aboveground biomass }(\mathrm{kg}),
\end{aligned}
$$




$$
\begin{aligned}
& \rho=\operatorname{Density}\left(\mathrm{gcm}^{-3}\right), \\
& \mathrm{D}=\operatorname{Dbh}(\mathrm{cm}) .
\end{aligned}
$$

The maximum diameter at breast height for which this equation is reliable is $148 \mathrm{~cm}$.

To estimate the carbon stock of the below-ground biomass (BGBC), the equation from [17] was used. The equation is stated thus;

$$
\begin{aligned}
& \mathrm{BGBC}=0.235 \times A \mathrm{~GB} \text { If } \mathrm{AGBC}>62.5 \mathrm{tC} / \mathrm{ha} \\
& \mathrm{BGBC}=0.205 \times \mathrm{AGB} \text { If } \mathrm{AGBC} \leq 62.5 \mathrm{tC} / \mathrm{ha}
\end{aligned}
$$

Since woody biomass is $50 \%$ carbon [18], the carbon content of each component for individual tree was estimated by dividing the biomass by two. This method was also adopted by [19].

$$
\text { Carbon }=\frac{\text { Biomass }}{2}(\text { tonnes })
$$

\section{Results and Discussion}

\subsection{Forest Structure}

The summary of the tree growth variables for the selected species is presented in Table 1. Their mean height, diameter at breast height and density are $441 \mathrm{~cm}$, $4.53 \mathrm{~cm}$ and $0.83 \mathrm{~g} / \mathrm{cm}^{3}$ respectively. However, Terminalia superba had the highest tree height and Dbh average of $520 \mathrm{~cm}$ and $5.8 \mathrm{~cm}$ respectively, while Triplochiton scleroxylon had the lowest tree height and Dbh average of $377.5 \mathrm{~cm}$ and $3.55 \mathrm{~cm}$ respectively. Wood density of selected tree species in the study area ranged from $0.67 \mathrm{~g} / \mathrm{cm}^{3}$ for Terminalia superba species to $0.91 \mathrm{~g} / \mathrm{cm}^{3}$ for Treculia rhinopetala species (Table 1). This study points out that the forest under consideration is a young forest as the Dbh of the trees measured and used is less than $10 \mathrm{~cm}$ i.e. Dbh $>10 \mathrm{~cm}$ [20]. However, this study was done for a plot of the study area which is equivalent to 1 hectare. For the distribution of trees by diameter class, the following observations were recorded; 15 trees had diameter class between $0-5 \mathrm{~cm}$ and 5 trees had diameter class between $5-10 \mathrm{~cm}$. The total number of trees measured in this study for the study site was twenty trees. Table 2 demonstrates the distribution of the selected trees in the whole plot based on diameters.

Table 1. Summary of raw data of tree species.

\begin{tabular}{cccc}
\hline Species & Height $(\mathrm{cm})$ & Dbh $(\mathrm{cm})$ & Density $\left(\mathrm{g} / \mathrm{cm}^{3}\right)$ \\
\hline Terminalia superba & 520 & 5.8 & 0.67 \\
Triplochiton scleroxylon & 378 & 3.6 & 0.87 \\
Clestopholips patens & 440 & 5.2 & 0.89 \\
Treculia rhinopetala & 366 & 3.6 & 0.91 \\
Antiaris Africana & 500 & 4.5 & 0.82 \\
Mean & 441 & 4.53 & 0.83 \\
\hline
\end{tabular}


Table 2. Distribution of trees selected by diameter class.

\begin{tabular}{cccc}
\hline Species & $\mathrm{NT}_{1}(1-5 \mathrm{~cm})$ & $\mathrm{NT}_{2}(5-10 \mathrm{~cm})$ & $\mathrm{TT}$ \\
\hline Terminalia superba & 2 & 2 & 4 \\
Triplochiton scleroxylon & 4 & 0 & 4 \\
Clestopholis patens & 2 & 2 & 4 \\
Treculia rhinopetala & 5 & 0 & 4 \\
Antiaris Africana & 3 & 1 & 4 \\
TT & 15 & 5 & 20
\end{tabular}

TT: Total of trees; $\mathrm{NT}_{1}$ : Number of trees with diameter class $1-5 \mathrm{~cm}$ of Dbh; $\mathrm{NT}_{2}$ : Number of trees with diameter class $5-10 \mathrm{~cm}$ of Dbh.

\subsection{Soil Physio-Chemical Properties of Experimental Field}

The soils of the experimental site were predominantly Sandy Clay Loam according to USDA soil textural classification [21]. The descriptive statistics of particle size distribution of the site indicate that the soils generally have an average sand content of $51 \% \pm 7.46 \%$ with an average silt content of $18 \% \pm 5.67 \%$ and the average clay content is $31 \% \pm 6.04 \%$ (Table 3). Meanwhile, values for the OMC at the experimental field are similar to those reported by [22] [23]. There was no significant difference in the mean values of $\mathrm{pH}$ down the soil layers but there was a slight decrease in the mean OMC with depth. High organic matter content was also observed in the forest soil $(8.02 \% \pm 2.88 \%)$ which is attributed to the continuous accumulation of undecayed and partially decomposed plant and animal residues in the surface soil. The presence of high nutrient in the forest land can help to support agro-forestry. Similar results were obtained by [24] in their work on land use effects on soil erodibility and hydraulic conductivity in Akure, Nigeria.

\subsection{Biomass and Carbon Stock Estimation}

For the entire study area, it was observed that carbon stock is higher in above-ground biomass with $0.00407 \mathrm{t} \mathrm{C}$ compared to below-ground biomass with $0.00167 \mathrm{t} \mathrm{C}$ (Figure 2). From this total, the aboveground and belowground carbon stock represented $71 \%$ and $29 \%$ respectively. It was determined that in this tropical forest, the total carbon stock (AGBC + BGBC) was $0.00573 \mathrm{t} \mathrm{C}$ (Tables 4-6). Terminalia superba $(0.00698 \mathrm{t} \mathrm{C})$ has the highest carbon stocks while the Triplochiton scleroxylon contained the least stock of carbon $(0.00212 \mathrm{t}$ C). Figure 3 shows the average of AGBC and BGBC of selected species in the study area.

\subsection{Modeling of above Ground Biomass (AGB) versus Dbh, WD and $\mathrm{H}$}

Regression analysis was carried out to generate three different models for the aboveground biomass with different input parameters (Figure 4). Equations (7)-(9) present the different models. An equation that relates AGB and BGB was also derived (Equation (10)). 


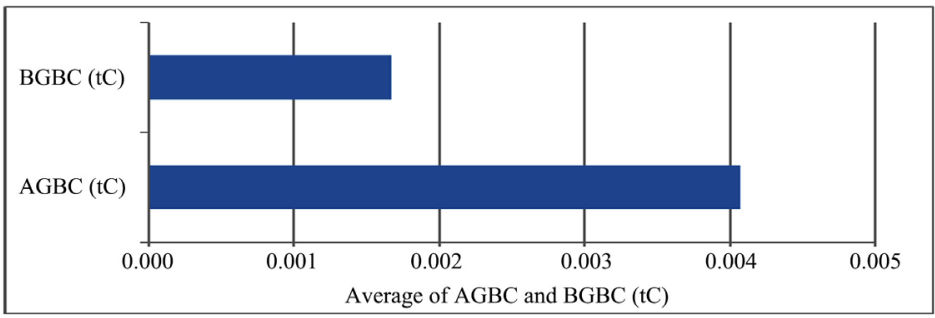

Figure 2. Average of AGBC and BGBC in the forest land.

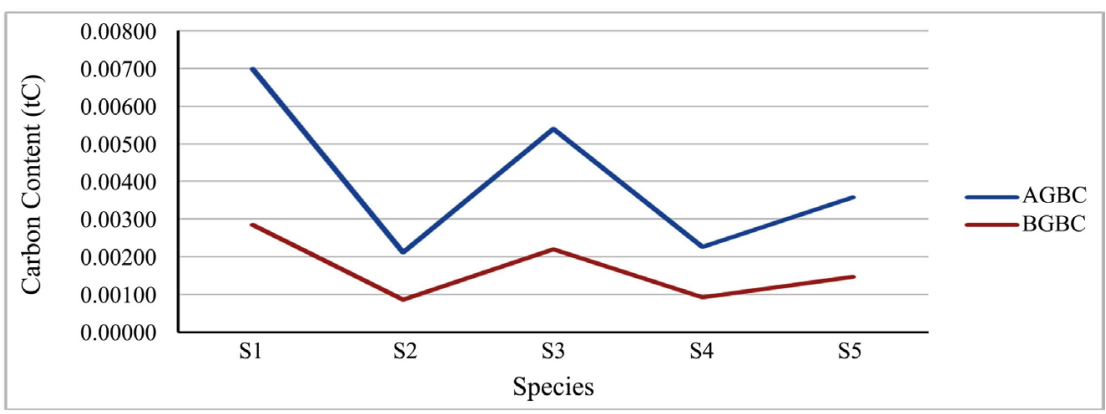

Figure 3. Average of AGBC and BGBC of selected species.

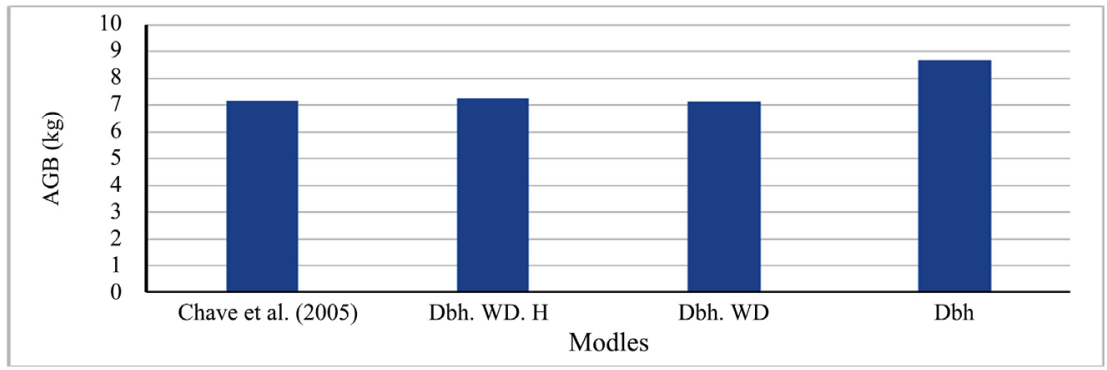

Figure 4. Comparison of new models (I, II, III).

Table 3. Descriptive statistics of organic matter content (OMC), particle size distribution and $\mathrm{pH}$ of the experimental field.

\begin{tabular}{cccccc}
\hline Variable & Mean & StDev & Minimum & Median & Maximum \\
\hline OMC, \% & 8.02 & 2.88 & 2.07 & 8.75 & 12.23 \\
Clay, \% & 31.00 & 6.04 & 10.00 & 30.00 & 46.00 \\
Silt, \% & 18.00 & 5.67 & 4.00 & 16.00 & 28.00 \\
Sand, \% & 51.00 & 7.46 & 34.00 & 50.00 & 74.00 \\
pH & 6.13 & 0.70 & 5.18 & 6.08 & 6.91
\end{tabular}

Table 4. Summary of AGBC and BGBC for the entire plot.

\begin{tabular}{cccc}
\hline Specie & AGBC (t C) & BGBC (t C) & AGBC + BGBC (t C) \\
\hline Terminalia superba (S1) & 0.00698 & 0.00286 & 0.00984 \\
Triplochiton scleroxylon (S2) & 0.00212 & 0.00087 & 0.00298 \\
Clestopholis patens (S3) & 0.00540 & 0.00221 & 0.00761 \\
Treculia rhinopetala (S4) & 0.00227 & 0.00093 & 0.00320 \\
Antiaris Africana (S5) & 0.00357 & 0.00147 & 0.00504 \\
Mean & 0.00407 & 0.00167 & 0.00573
\end{tabular}


Table 5. Summary of selected trees in the entire plot.

\begin{tabular}{|c|c|c|c|}
\hline Specie & Height $(\mathrm{cm})$ & $\mathrm{Dbh}(\mathrm{cm})$ & Density $\left(\mathrm{g} / \mathrm{cm}^{3}\right)$ \\
\hline \multicolumn{4}{|c|}{ Terminalia superba } \\
\hline $1 \mathrm{~A}$ & 430 & 4.0 & 0.56 \\
\hline $1 \mathrm{~B}$ & 400 & 5.0 & 0.67 \\
\hline $1 \mathrm{C}$ & 600 & 5.2 & 0.61 \\
\hline $1 \mathrm{D}$ & 650 & 9.0 & 0.84 \\
\hline \multicolumn{4}{|c|}{ Triplochiton scleroxylon } \\
\hline $2 \mathrm{~A}$ & 395 & 4.2 & 0.87 \\
\hline $2 \mathrm{~B}$ & 350 & 3.1 & 1.00 \\
\hline $2 \mathrm{C}$ & 380 & 3.0 & 0.74 \\
\hline $2 \mathrm{D}$ & 385 & 3.9 & 0.87 \\
\hline \multicolumn{4}{|c|}{ Clestopholis patens } \\
\hline $3 \mathrm{~A}$ & 445 & 4.8 & 0.85 \\
\hline $3 \mathrm{~B}$ & 410 & 4.8 & 0.79 \\
\hline $3 \mathrm{C}$ & 428 & 5.2 & 0.94 \\
\hline $3 \mathrm{D}$ & 477.5 & 6.0 & 0.98 \\
\hline \multicolumn{4}{|c|}{ Treculia rhinopetala } \\
\hline $4 \mathrm{~A}$ & 350 & 4.0 & 0.89 \\
\hline $4 \mathrm{~B}$ & 410 & 3.5 & 0.96 \\
\hline $4 \mathrm{C}$ & 355 & 3.0 & 0.89 \\
\hline $4 \mathrm{D}$ & 350 & 4.0 & 0.88 \\
\hline \multicolumn{4}{|c|}{ Antiaris Africana } \\
\hline $5 \mathrm{~A}$ & 490 & 4.5 & 0.84 \\
\hline $5 \mathrm{~B}$ & 580 & 6.0 & 0.80 \\
\hline $5 \mathrm{C}$ & 590 & 4.2 & 0.72 \\
\hline $5 \mathrm{D}$ & 340 & 3.2 & 0.90 \\
\hline
\end{tabular}

Table 6. Biomass (t) and carbon content $(\mathrm{tC})$ of sample trees.

\begin{tabular}{ccccc}
\hline Specie & \multicolumn{2}{c}{ Biomass $(\mathrm{t})$} & \multicolumn{2}{c}{ Carbon content $(\mathrm{tC})$} \\
\hline & Stem & Root & Stem & Root \\
Terminalia superba & & & & \\
1A & 0.00349 & 0.00143 & 0.00174 & 0.00071 \\
1B & 0.00714 & 0.00293 & 0.00357 & 0.00146 \\
1C & 0.00715 & 0.00293 & 0.00358 & 0.00147 \\
1D & 0.03803 & 0.01559 & 0.01902 & 0.00780 \\
Triplochiton scleroxylon & & & & \\
2A & 0.00609 & 0.00250 & 0.00304 & 0.00125 \\
\hline
\end{tabular}




\section{Continued}

\begin{tabular}{|c|c|c|c|c|}
\hline $2 \mathrm{~B}$ & 0.00341 & 0.00140 & 0.00170 & 0.00070 \\
\hline $2 \mathrm{C}$ & 0.00233 & 0.00096 & 0.00117 & 0.00048 \\
\hline $2 \mathrm{D}$ & 0.00510 & 0.00209 & 0.00255 & 0.00105 \\
\hline \multicolumn{5}{|c|}{ Clestopholis patens } \\
\hline $3 \mathrm{~A}$ & 0.00821 & 0.00337 & 0.00410 & 0.00168 \\
\hline 3B & 0.00763 & 0.00313 & 0.00381 & 0.00156 \\
\hline $3 \mathrm{C}$ & 0.01103 & 0.00452 & 0.00551 & 0.00226 \\
\hline $3 \mathrm{D}$ & 0.01630 & 0.00668 & 0.00815 & 0.00334 \\
\hline \multicolumn{5}{|c|}{ Treculia rhinopetala } \\
\hline $4 \mathrm{~A}$ & 0.00554 & 0.00227 & 0.00277 & 0.00114 \\
\hline $4 \mathrm{~B}$ & 0.00435 & 0.00178 & 0.00218 & 0.00089 \\
\hline $4 \mathrm{C}$ & 0.00281 & 0.00115 & 0.00140 & 0.00058 \\
\hline $4 \mathrm{D}$ & 0.00548 & 0.00225 & 0.00274 & 0.00112 \\
\hline \multicolumn{5}{|c|}{ Antiaris Africana } \\
\hline $5 \mathrm{~A}$ & 0.00694 & 0.00285 & 0.00347 & 0.00142 \\
\hline $5 \mathrm{~B}$ & 0.01331 & 0.00546 & 0.00665 & 0.00273 \\
\hline $5 \mathrm{C}$ & 0.00504 & 0.00207 & 0.00252 & 0.00103 \\
\hline $5 \mathrm{D}$ & 0.00330 & 0.00135 & 0.00165 & 0.00068 \\
\hline
\end{tabular}

1) New model I with $\mathrm{Dbh}, \mathrm{WD}$, and $\mathrm{H}$ as input

$$
\begin{aligned}
\mathrm{AGB}= & 10.26+0.00617(\mathrm{H})-5.731(\mathrm{Dbh})-9.39(\rho) \\
& +0.7562\left(\mathrm{Dbh}^{2}\right)-0.001409(\mathrm{H} \times \mathrm{Dbh})+3.994(\mathrm{Dbh} \times \rho)
\end{aligned}
$$

2) New model II with Dbh and WD as input

$$
\mathrm{AGB}=12.946-6.074(\mathrm{Dbh})-10.88(\rho)+0.69103\left(\mathrm{Dbh}^{2}\right)+4.348(\mathrm{Dbh} \times \rho)
$$

3) New model III with only Dbh as input

$$
\begin{gathered}
\mathrm{AGB}=5.178-3.012(\mathrm{Dbh})+0.7427\left(\mathrm{Dbh}^{2}\right) \\
\mathrm{BGB}=0.32 \mathrm{AGB}
\end{gathered}
$$

\section{Discussion}

Young forest when growing rapidly, can sequester relatively large volumes of carbon roughly proportional to the forest's growth in biomass [25]. An old-growth forest acts as a reservoir, holding large volumes of carbon even if it is not experiencing net growth. An average AGBC of $0.00407 \mathrm{t} \mathrm{C}$ was discovered in the selected trees in the study area. Thus, a young forest holds less carbon, but will sequester additional carbon over time. While an old forest may not be capturing any new carbon but can continue to hold large volumes of carbon as biomass over long periods of time [9]. There is a positive linear relationship between Dbh 
and the amount of carbon in the study area as shown in Table 3. This result agrees with the work of [3] on their assessment of carbon stocks in tropical rainforests in Ile-Ife, Nigeria. The diameter distribution of the species of the study area as presented in Table 2 revealed that the highest number of trees selected occurred in the Dbh class of $0-5 \mathrm{~cm}$. The wood density in tree trunks holds obvious importance for the amount of carbon stored in the forest [1]. Wood density of study area ranged from 0.67 to $0.91 \mathrm{~g} / \mathrm{cm}^{3}$. It was observed that a negative linear relationship exists between the AGBC and wood densities. Treculia rhinopetala had the highest density and corresponding lowest amount of AGBC present. Similar results were obtained by [4] in their work on carbon stocks of selected forest reserves in South-western Nigeria. The amount or carbon stock for AGB + BGB in a study plot is still not affected by the number of species in this plot. Thus, the stock of carbon (AGB + BGB) in this study plot is influenced by biological type of species that constitute this study plot. The results of this study show that plots dominated by species of the family of Terminalia superba contain higher carbon stock relative to other families. This is supported by the work of [25] who estimated carbon stock in secondary forests within the Panama Canal Watershed. Biomass and carbon stock are not based on the number of trees, but rather related to diameter at breast height and wood density [5]. It was found in this study that for above ground biomass, the Terminalia superba $(0.00698 \mathrm{t} \mathrm{C})$ has the highest carbon stocks and Dbh of $5.8 \mathrm{~cm}$ while Triplochiton scleroxylon contains least stocks of carbon $(0.00212 \mathrm{t} \mathrm{C})$ and Dbh of $3.55 \mathrm{~cm}$. The high carbon stock in the study area is potentially due to its natural reserve of flora and fauna, and by being a forest ecosystem with minimal disturbance. New models were developed with different input parameters and compared to the allometric model from [13]. Difference between the new models and model from [13] range from -1.549 (New model I) to -0.10474 (New model II). All new models showed proximity model from [13] and are therefore available for use in further research with any of the parameters if the forest being considered is a young forest i.e. $\mathrm{Dbh}>10 \mathrm{~cm}$ [20].

\section{Conclusion}

The findings of this study demonstrate the capacity of the forest ecosystem to significantly sequester carbon. The results of this study indicate that throughout this forest, the average aboveground carbon stock of live trees is $0.00407 \mathrm{t}$. Terminalia superba $(0.00698 \mathrm{t} \mathrm{C}$ ) has the highest carbon stocks and Dbh of $5.8 \mathrm{~cm}$ while Triplochiton scleroxylon contains least stocks of carbon $(0.00212 \mathrm{t} \mathrm{C})$ and Dbh of $3.55 \mathrm{~cm}$. Terminalia superba is the most dominant in terms of carbon stocks in the study area while Triplochiton scleroxylon is the least. The choice of an appropriate allometric model is a critical step in reducing uncertainties in forest biomass stock estimates. The forests in the study area are important carbon reservoir and have the potential to form chief component in the mitigation of global warming and adaptation to climate change. Results suggest that avoid- 
ing deforestation and improving forest management could play a major role in global climate change mitigation. Estimation of the carbon stocks will enable the assessment of the amount of carbon loss during deforestation. Therefore, knowing the carbon stocks of the selected forest is important to contribute to the proper management of this forest ecosystem. The potential of carbon stocks capacity in tropical forest may also help the country to earn carbon credits.

\section{Conflicts of Interest}

The authors declare no conflicts of interest regarding the publication of this paper.

\section{References}

[1] Genene, A., Tefera, M., Zerihun, G. and Solomon, Z. (2013) Forest Carbon Pools and Carbon Assessment in the Context of SFM and REDD+. Wondo Genet, Ethiopia, $69 \mathrm{p}$.

[2] Kridiborworn, P., Chidthaisong, A., Yuttitham, M. and TripetChkul, S. (2012) Carbon Sequestration by Mangrove Forest Planted Specifically for Charcoal Production Yeesarn, Samut Songkhram. Journal of Sustainable Energy and Environment, 3, 87-92.

[3] Onome, O.A. and Anthony, I.O. (2016) Carbon Stock in Different Pools across Different Vegetation Structures in a Tropical Rainforest in Ile-Ife, Nigeria. International Journal of Plant \& Soil Science, 10, 1-10. https://doi.org/10.9734/IJPSS/2016/23719

[4] Olufunke, O.O., Saka, O.B. and Labode, P. (2015) Carbon Stock in Teak Stands of Selected Forest Reserves in South-Western Nigeria. Environment and Natural Resources Research, 5, 109-115. https://doi.org/10.5539/enrr.v5n3p109

[5] Ekoungoulou, R., Niu, S., Loumeto, J.J., Ifo, S.A., Bocko, Y.E., Mikieleko, F.E., Guiekisse, E.D., Senou, H. and Liu, X. (2015) Evaluating the Carbon Stock in Above- and Below-Ground Biomass in a Moist Central African Forest. Applied Ecology and Environmental Sciences, 3, 51-59.

[6] IPCC (Intergovernmental Panel on Climate Change) (2007) Mitigations of Climate Change: Contribution of Working Group III to the Fourth Assessment Report of the Intergovernmental Panel on Climate Change. Cambridge University Press, New York.

[7] Prentice, C., Heimann, M. and Sit Ch, S. (2000) The Carbon Balance of the Terrestrial Biosphere: Ecosystem Models and Atmospheric Observations. Ecological Applications, 10, 1553-1573. https://doi.org/10.1890/1051-0761(2000)010[1553:TCBOTT]2.0.CO;2

[8] Ravindranath, N.H. and Ostwald, M. (2008) Methods for Estimating Above-Ground Biomass, Carbon Inventory Methods. In: Handbook for Greenhouse Gas Inventory, Carbon Mitigation and Roundwood Production Projects, Springer Science + Business Media, Berlin, 113-114. https://doi.org/10.1007/978-1-4020-6547-7_10

[9] Losi, C.J., Siccama, T.G., Condit, R. and Morales, J.E. (2003) Analysis of Alternative Methods for Estimating Carbon. Forest Ecology and Management, 184, 355-368. https://doi.org/10.1016/S0378-1127(03)00160-9

[10] American Carbon Registry (2012) Estimation of Carbon Stocks in Tree Biomass (CP-TB). Tiera Resources LLC, New Orleans, 13 p. 
[11] Fasinmirin, J.T. and Adesigbin, A.J. (2012) Degree of Compaction and Compression Strength of Nigerian Alfisol under Tilled Condition and Different Machinery Traffic Passes. International Journal of Agricultural and Biological Engineering, 5, 34-41.

[12] Aremu, O.T., Emelue, G.U., Osayimwen, F.E. and Obasogie, F.O. (2012) Estimate of Habitat Quality of White Throated Monkey (Ceropithecus erythrogaster) in Okomu National Park, Nigeria. Nigerian Journal of Agriculture, Food and Environment, 8, 47-51.

[13] Chave, J., Andalo, C., Brown, S., Cairns, M.A., Chambers, J.Q., Eamus, D., Fölster, H., Fromard, F., Higuchi, N., Kira, T., Lescure, J.P., Nelson, B.W., Ogawa, H., Puig, H., Riera, B. and Yamakura, T. (2005) Tree Allometry and Improved Estimation of Carbon Stocks and Balance in Tropical Forests. Oecologia, 145, 87-99. https://doi.org/10.1007/s00442-005-0100-x

[14] Cai, S., Kang, X. and Zhang, L. (2013) Allometric Models for Aboveground Biomass of Ten Tree Species in Northeast China. Annals of Forest Research, 56, 105-122.

[15] Wenger, K. (2004) Forestry Handbook. 2nd Edition, John Wiley \& Sons, Inc., New York, $1335 \mathrm{p}$.

[16] Wiemann, M.C. and Williamson, G.B. (2012) Density and Specific Gravity Metries in Biomass Research. Forest Products Laboratory, Forest Service, United States Department of Agriculture, Washington DC, $6 \mathrm{p}$. https://doi.org/10.2737/FPL-GTR-208

[17] Mokany, K., Raison, R.J. and Prokushkin, A.S. (2006) Critical Analysis of Root: Shoot Ratios in Terrestrial Biomes. Global Change Biology, 12, 84-96. https://doi.org/10.1111/j.1365-2486.2005.001043.x

[18] Coomes, D.A., Allen, R.B., Scott, N.A., Goulding, C. and Beets, P. (2001) Designing Systems to Monitor Carbon Stocks in Forests and Shrub Lands. Forest Ecology and Management, 5641, 1-20. https://doi.org/10.1016/S0378-1127(01)00592-8

[19] Ekoungoulou, R., Liu, X., Ifo, S.A., Loumeto, J.J. and Folega, F. (2014) Carbon Stock Estimation in Secondary Forest and Gallery Forest of Congo Using Allometric Equations. International Journal of Scientific and Technology Research, 3, 465-474.

[20] FAO (2008) Market Penetration of Developing Country Seafood Products in European Retail Chains. Globefish Research Programme, Vol. 90, Rome, 56 p.

[21] Soil Survey Staff (1999) Soil Taxonomy: A Basic System of Soil Classification for Making and Interpreting Soil Surveys. 2nd Edition, Natural Resources Conservation Service, U.S. Department of Agriculture Handbook, Washington DC, 436.

[22] Adekiya, A.O.L., Ojeniyi, S.O.L., and Agbede, T.M. (2011) Tillage Effects on Soil Properties, Growth and Yield of Cocoyam (Xanthosomasa gittifolium Schott) on an Alfisol of Southwest, Nigeria. 385-395.

[23] Fasinmirin, J.T. and Olorunfemi, I.E. (2013) Soil Moisture Content Variation and Mechanical Resistance of Nigerian Alfisol under Different Tillage Systems. Journal of Agricultural Engineering and Technology, 21, 11-20.

[24] Yusuf, H.A., Oguntunde, P.G. and Lawal, A.K. (2018) Land Use Effects on Soil Erodibility and Hydraulic Conductivity in Akure, Nigeria. African Journal of Agricultural Research, 13, 329-337. https://doi.org/10.5897/AJAR2017.12947

[25] Breugel, V.M. (2011) Estimating Carbon Stock in Secondary Forests: Decisions and Uncertainties Associated with Allometric Biomass Models. Forest Ecology and Management, 262, 1648-1657. https://doi.org/10.1016/j.foreco.2011.07.018 